\title{
Bound Ascorbic Acid in Acerola Juice ${ }^{1,2}$
}

\author{
Alice del Campillo and Conrado F. Asenjo ${ }^{3}$ \\ INTRODUCTION AND OBJECTIVE
}

The unusually high content of ascorbic acid in acerola juice $(1,2,3)^{4}$ suggests that some of it may occur in the bound form. Consideration of this possibility resulted in the present investigation of the chemical state of ascorbic acid in that juice.

\section{LITERATURE REVIEW}

McHenry (4) and Ahmad (5) were the first to point out the possible presence of a combined form of ascorbic acid in plant tissue. Precipitates containing bound ascorbic acid were obtained by Reedman and McHenry from plant extracts $(6)$. Holtz and Walter ( 7$)$ determined bound ascorbic acid in animal tissue. Since then much work has been done on bound ascorbic acid and it has been the subject of considerable controversy, as many investigators have questioned the existence of a bound form of this vitamin.

Sumerwell and Sealock (8) developed a method that established the presence of appreciable amounts of bound ascorbic acid in liver tissue. Their results were verified in this laboratory by Jeffay (9). According to the technique of Sumerwell and Sealock (8), bound ascorbic acid is the ascorbic acid not extracted by 95-percent ethanol, and which can be determined only after the ethanol-insoluble fraction is subjected to acid hydrolysis.

\section{METHODS}

The method of Sumerwell and Sealock (8), with some modifications in order to adapt it to the acerola juice, was used. It consists in extracting the free ascorbic acid in the juice with 3 volumes of ice-cold ethanol in an atmosphere of carbon dioxide. After washing the precipitate nine times with ethanol, it was hydrolyzed in 5-percent metaphosphoric acid to release the bound ascorbic acid. The hydrolysis was accomplished by adding 1.5 volumes (with respect to the original volume of juice) of 5-percent metaphosphoric acid and heating the mixture for 15 minutes in a boiling water

1 This investigation was made possible by a grant made to one of us (C.F.A.) by the Guggenheim Foundation.

${ }^{2}$ A preliminary report of this work was presented by the authors at the meeting of the Federation of Biological Societies in Atlantic City, Apr. 16-20, 1956.

${ }^{3}$ Department of Biochemistry and Nutrition, School of Medicine, School of Tropical Medicine, University of Puerto Rico, San Juan 22, P. R.

'Italic numbers in parentheses refer to Literature Cited, p. 139. 
bath while passing carbon dioxide. After cooling, the mixture was diluted with 5-percent metaphosphoric acid to a definite volume, filtered, and the ascorbic acid liberated determined.

The ascorbic acid was determined by the routine method of Roe and Kuether (10). The ascorbic acid was first oxidized to dehydroascorbic acid with saturated bromine water, as described by Roe and Oesterling (11), until a faint, permanent yellow color was produced. The color of the excess bromine was removed by aeration or by adding a few drops of a solution of 10-percent thiourea in 50-percent ethanol. The dehydroascorbic acid was then coupled with 2,4-dinitrophenylhydrazine to form the osazone, following the method of Roe and Kuether (10). The osazone thus formed reacts with 85-percent sulfuric acid to give a red-orange complex. The intensity of the color of this complex was read against a reagent blank in the Evelyn photoelectric colorimeter using filter No. 54 .

The micromethod of Bessey (12) for ascorbic and dehydroascorbic acid was also used with some modifications. In order to convert any dehydroascorbic acid to ascorbic acid the samples were treated with hydrogen sulfide. The excess hydrogen sulfide was removed by gassing extensively with wet-tank nitrogen. The measurements were made in a Beckman DU-Spectrophotometer at $518 \mathrm{~m} \mu$. The method consists in following the decrease in absorption at the indicated wavelength, when a solution of ascorbic acid is added to a solution of 2,6-dichlorophenolindophenol at a $\mathrm{pH}$ of 3.7. The decrease in absorption observed in the first 15 seconds was used for the calculation of the amount of ascorbic acid present in the sample. A solution of known content of ascorbic acid was used as reference.

\section{RESULTS \\ EXTRACTION OF FREE ASCORBIC ACID}

The results of a typical extraction procedure appear in table 1 . To 10 $\mathrm{ml}$. of acerola juice containing about $100 \mathrm{mg}$. of ascorbic acid, $30 \mathrm{ml}$. of ice-cold 95-percent alcohol were added. Immediately a precipitate appeared which was centrifuged off. A large proportion of the free ascorbic acid present in the juice was removed by this first ethanol extraction. Although practically all the free ascorbic acid had been removed after the fifth extraction with $30-\mathrm{ml}$. volumes of ethanol, the precipitate was still washed five more times. The last two washings contained practically no ascorbic acid. However, in order fully to rule out the possibility that the precipitate could have occluded free ascorbic acid, it was extracted in a Potter-Elvehjem homogenizer with ethanol, at room temperature, for 5 to 10 minutes. The alcoholic extract thus obtained contained no ascorbic acid, as determined by the 2,4-dinitrophenylhydrazine method. Yet the residue left behind yielded additional ascorbic acid after acid hydrolysis. 


\section{LIBERATION OF ASCORBIC ACID FROM THE PRECIPITATE}

The precipitate was hydrolyzed at $100^{\circ} \mathrm{C}$. with 5-percent metaphosphoric acid by the procedure already described. It contained 0.19 percent

TABLE 1.-Results of using the typical extraction procedure described in the text on juice of the acerola

\begin{tabular}{|c|c|c|}
\hline Treatment & Extraction No. ${ }^{1}$ & Total ascorbic acid \\
\hline $\begin{array}{l}\text { Precipitate homogenized } \\
\text { Bound ascorbic acid4 }\end{array}$ & $\left.\begin{array}{c}1 \\
2 \\
3 \\
4 \\
5 \\
6 \\
6 \\
7 \\
8\end{array}\right\}$ & 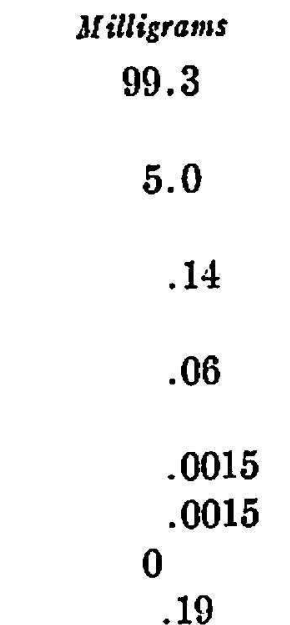 \\
\hline
\end{tabular}

1 The braces indicate that extractions 2 and $3 ; 4$ and 5 ; and 6,7 , and 8 were combined into 1 sample each before the ascorbic acid assay was performed.

${ }^{2}$ Extraction of free ascorbic acid from $10 \mathrm{ml}$. of acerola juice with ethanol.

3 Precipitate extracted in a homogenizer.

4 Bound ascorbic acid liberated from precipitate by acid hydrolysis.

5 Acid hydrolysis of precipitate.

TABLE 2.-Total and bound ascorbic acid found present in 6 samples of acerola juice

\begin{tabular}{c|c|c|c|c}
\hline Sample No. & Juice & $\begin{array}{c}\text { Total ascorbic } \\
\text { acid present }\end{array}$ & $\begin{array}{c}\text { Bound ascorbic } \\
\text { acid present }\end{array}$ & Proportion bound \\
\cline { 2 - 3 } 1 & Millititers & Milligrams & Jfilligrams & Percent \\
2 & 10 & 100 & 0.15 & 0.15 \\
3 & 10 & 100 & .16 & .16 \\
4 & 10 & 100 & .19 & .19 \\
5 & 100 & 1,000 & 2.3 & .23 \\
6 & 200 & 2,000 & 3.3 & .17 \\
\hline
\end{tabular}

of the total ascorbic acid in the juice. In table 2 are recorded the results obtained in six determinations of different samples of ripe acerola juice. The percentage of bound ascorbic acid ranged from 0.15 to 0.23 , averaging 0.18 percent of the total ascorbic acid present in the juice.

If the hydrolysis were carried out at room temperature $\left(27^{\circ} \mathrm{C}\right.$.) for the 
same period of time, only 43 percent of the bound ascorbic acid found was liberated.

AMOUNT AND NATURE OF PRECIPITATE CONTAINING BOUND ASCORBIC ACID

The yield of the precipitate containing bound ascorbic acid ranged between 0.19 and 0.23 percent, averaging 0.22 percent by weight of juice as indicated in table 3 . The juice from acerolas kept frozen for several months, as well as canned juice, were found to contain about the same amount of bound ascorbic acid as the fresh acerola juice.

The precipitate was insoluble in water and contained from 1.0 to 1.5 percent of nitrogen. It did not contain sulfur or halogens. Qualitative tests for proteins such as biuret, ninhydrin, and Millons were negative; the xanthoproteic test, however, was positive. The precipitate gave a positive Molisch test, but a negative starch-iodine test. The Benedict test for re-

TABLE 3.-Weight and yield of precipilate containing bound ascorbic acid obtained from 4 samples of acerola juice

\begin{tabular}{c|c|c|c|c}
\hline Sample No. & Juice & Weight of juice & Weight of precipitate & Yield \\
\cline { 2 - 3 } 1 & Millilifers & Grams & Milligrams & Percenl \\
2 & 10 & 10.4 & 19.5 & 0.19 \\
3 & 100 & 104.0 & 236.0 & .23 \\
4 & 200 & 208.0 & 455.0 & .22 \\
& 200 & 208.0 & 480.0 & .23 \\
\hline
\end{tabular}

ducing sugars was positive only after acidification and neutralization, indicating that the liberated ascorbic acid was probably the responsible reducing agent.

\section{CHARACTERIZATION OF LIBERATED ASCORBIC ACID}

Attempts to isolate the ascorbic acid osazone prepared from the ascorbic acid released from the bound complex were not altogether successful. The method of Sumerwell and Sealock (8) was used and it was possible to follow the formation of the osazone in the incubation mixture. However, the solid obtained, which should have been the ascorbic acid osazone, had an indefinite melting point due to impurities. Attempts to purify this precipitate were unsuccessful because the amount available was very small. After two reprecipitations the material showed charring at $200^{\circ} \mathrm{C}$.

The red-orange-colored complex formed by the reaction of the dehydroascorbic acid osazone with 85-percent sulfuric acid was used to characterize the liberated ascorbic acid. The absorption spectrum of this red-orange complex after dilution in a 1:1 ethanol-acetone mixture was determined 
in a Beckman DU-Spectrophotometer. The blank cell contained the same reagents as the experimental cell, the only difference being the order in which the reagents were added. Figure 1 shows the absorption curves obtained with pure ascorbic acid and with ascorbic acid released by acid hydrolysis of the solid fraction. Both curves are very similar with a maximum at $440 \mathrm{~m} \mu$.

In order to provide additional evidence that the reducing agent liberated after acid hydrolysis of the precipitate was ascorbic acid, this was determined in the same sample by the 2,4-dinitrophenylhydrazine method and by the Bessey micromethod (12) using 2,6-dichlorophenolindophenol. The

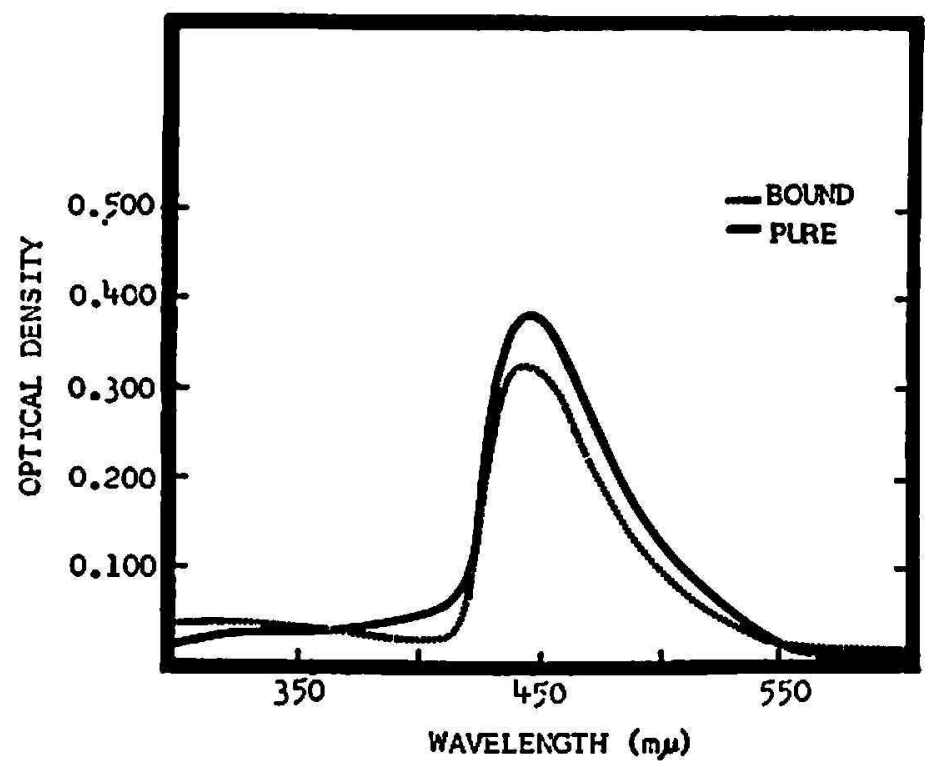

FIG. 1.-Absorption curves obtained with pure ascorbic acid and with ascorbic acid released by acid hydrolysis of the solid fraction.

yield of ascorbic acid by both methods was practically identical: 8.09 $\mu \mathrm{g} . / \mathrm{mg}$. and $8.07 \mu \mathrm{g} . / \mathrm{mg}$., respectively.

\section{SUMMAIRY}

1. Acerola juice, fresh, frozen, or canned, was found to contain in the neighborhood of 0.22 percent by weight of an alcohol-insoluble precipitate containing bound ascorbic acid. This precipitate contained about 1.25 percent of nitrogen.

2. Of the total ascorbic acid in acerola juice 0.18 percent was in the bound form.

3. The bound ascorbic acid liberated was characterized by means of the absorption spectrum curve of its osazone-sulfuric acid complex.

\section{RESUMEN}

1. El jugo de acerola fresco, congelado o enlatado contiene alrededor de 0.22 por ciento por peso de un precipitado insuluble en alcohol que en sí 
contiene ácido ascórbico conjugado. Este precipitado contiene cerca de 1.25 por ciento de nitrógeno.

2. Del total de ácido ascórbico en el jugo de acerola, 0.18 por ciento se encuentra en este estado conjugado.

3. El ácido ascórbico conjugado se liberó y se caracterizó por medio de la curva de absorción de su complejo osazona-ácido sulfúrico.

\section{LITERATURE CITED}

1. Asenjo, C. F. and Freire de Guzmán, A. R., The high ascorbic acid content of the West Indian cherry, Sci., 103 219, 1946.

2. Asenjo, C. F., Biological vitamin C activity of the Malpighia punicifolia L. pseudo cherry, Fed. Proc. Am. Soc. Exp. Biol., 10 158, 1951.

3. - Ensayo biológico de vitamina C en la cereza "Antillana", Arch. Ven. Nutr., 6 317-25, 1954.

4. McHenry, E. W., Observations on the estimation of ascorbic acid by titration, Biochem. J., 29 2013-9, 1935.

5. Ahmad, B., Estimation of ascorbic acid by titration, Nalure, $136797,1935$.

6. Reedman, E. J., and McHenry, E. W., Combined ascorbic acid in plant tissues, Biochem. J. 32 85-93, 1938.

7. Holtz, P., and Hedwig, W., Uber die gebundene ascorbinasaure tierischer geweke, Z. Physiol. Chem., 263 187-205, 1940.

8. Sumerwell, W. N., and Sealock, R. R., The determination of bound ascorbic acid in liver tissue, J. Biol. Chem., 196 753-9, 1952.

9. Jeffay, H., Occurrence and distribution of bound ascorbic acid in animal tissues, Fed. Proc. Am. Soc. Exp. Biol., 14 231, 1955.

10. Roe, J. H., and Kuether, C. A., The determination of ascorbic acid in whole blood and urine through the 2,4-dinitrophenylhydrazine derivative of dehydroascorbic acid, $J$. Biol. Chem., 147 399-407, 1943.

11. Roe, J. H., and Oesterling, M. J., The determination of dehydroascorbic acid and ascorbic acid in plant tissue by the 2,4-dinitrophenylhydrazine method, $J$. Biol. Chem., 152 511-7, 1944.

12. Bessey, O. A., A method for the determination of small quantities of ascorbic acid and dehydroascorbic ncid in turbid and colored solutions in the presence of other reducing substances, $J$. Biol. Chem., 126 771-84, 1938. 